\title{
THERMAL DECOMPOSITION OF SABUGALITE A controlled rate thermal analysis study
}

\author{
R. L. Frost ${ }^{1 *}$, J. Kristóf ${ }^{2}$, W. N. Martens ${ }^{2}$, M. L. Weier ${ }^{1}$ and Erzsébet Horváth ${ }^{3}$ \\ ${ }^{1}$ Inorganic Materials Research Program, School of Physical and Chemical Sciences, Queensland University of Technology \\ GPO Box 2434, Brisbane Queensland 4001, Australia \\ ${ }^{2}$ Department of Analytical Chemistry, University of Veszprém, 8201 Veszprém, P.O. Box 158, Hungary \\ ${ }^{3}$ Department of Environmental Engineering and Chemical Technology, University of Veszprém, 8201 Veszprém, P.O. Box 158 \\ Hungary
}

\begin{abstract}
The mineral sabugalite $(\mathrm{HAl})_{0.5}\left[\left(\mathrm{UO}_{2}\right)_{2}\left(\mathrm{PO}_{4}\right)\right]_{2} \cdot 8 \mathrm{H}_{2} \mathrm{O}$, has been studied using a combination of energy dispersive $\mathrm{X}$-ray analysis, $\mathrm{X}$-ray diffraction, dynamic and controlled rate thermal analysis techniques. X-ray diffraction shows that the starting material in the thermal decomposition is sabugalite and the product of the thermal treatment is a mixture of aluminium and uranyl phosphates. Four mass loss steps are observed for the dehydration of sabugalite at $48^{\circ} \mathrm{C}$ (temperature range 39 to $59^{\circ} \mathrm{C}$ ), $84^{\circ} \mathrm{C}$ (temperature range 59 to $109^{\circ} \mathrm{C}$ ), $127^{\circ} \mathrm{C}$ (temperature range 109 to $165^{\circ} \mathrm{C}$ ) and around $270^{\circ} \mathrm{C}$ (temperature range 175 to $525^{\circ} \mathrm{C}$ ) with mass losses of $2.8,6.5,2.3$ and $4.4 \%$, respectively, making a total mass loss of water of $16.0 \%$. In the CRTA experiment mass loss stages were found at $60,97,140$ and $270^{\circ} \mathrm{C}$ which correspond to four dehydration steps involving the loss of $2,6,6$ and 2 moles of water. These mass losses result in the formation of four phases namely meta(I)sabugalite, meta(II)sabugalite, meta(III)sabugalite and finally uranyl phosphate and alumina phosphates. The use of a combination of dynamic and controlled rate thermal analysis techniques enabled a definitive study of the thermal decomposition of sabugalite. While the temperature ranges and the mass losses vary due to the different experimental conditions, the results of the CRTA analysis should be considered as standard data due to the quasi-equilibrium nature of the thermal decomposition process.
\end{abstract}

Keywords: controlled rate thermal analysis (CRTA), dehydration, dehydroxylation, metasabugalite, sabugalite

\section{Introduction}

Layered uranyl phosphates and arsenates known as autunites or formerly as uranyl micas form one of the largest and most widespread groups of uranium minerals [1]. Many of these minerals may be found in quite widespread parts of Australia [2]. The minerals have a general formula $\mathrm{M}\left(\mathrm{UO}_{2}\right)_{2}\left(\mathrm{XO}_{4}\right)_{2} \cdot 8-12 \mathrm{H}_{2} \mathrm{O}$ where $M$ may be $\mathrm{Ba}, \mathrm{Ca}, \mathrm{Cu}, \mathrm{Fe}^{2+}, \mathrm{Mg}, \mathrm{Mn}^{2+}$ or $1 / 2(\mathrm{HAl})$ and $X$ is As, or P. In this mineral group there are also minerals based upon univalent cations. These include metaankoleite $(\mathrm{K})$, uramphite $\left(\mathrm{NH}_{4}\right)$, and sodiumuranospinite (Na). Autunites are common minerals, yet have been not often studied in terms of recent thermal analysis techniques or vibrational spectroscopy $[3,5,7-9]$. The minerals have a layer-like structure $[5,10,11]$. The minerals lend themselves to thermal analysis because of the low temperatures for the dehydration steps. A characteristic feature of the minerals is their layer structure in which uranium is bound in uranyl phosphate or uranyl arsenate layers. The cations and water are located in the interlayer space. Sabugalite has the formula $\mathrm{HAl}\left(\mathrm{UO}_{2}\right)_{4}\left(\mathrm{PO}_{4}\right)_{4} \cdot 16 \mathrm{H}_{2} \mathrm{O}$ and may be written as $\quad\left(\mathrm{H}_{3} \mathrm{O}\right)^{+} \mathrm{Al}\left(\mathrm{UO}_{2}\right)_{4}\left(\mathrm{PO}_{4}\right)_{4} \cdot 15 \mathrm{H}_{2} \mathrm{O}$ or as $\left(\mathrm{H}_{9} \mathrm{O}_{4}\right)^{+} \mathrm{Al}\left(\mathrm{UO}_{2}\right)_{4}\left(\mathrm{PO}_{4}\right)_{4} \cdot 12 \mathrm{H}_{2} \mathrm{O}$. It should be noted that the crystal structure of sabugalite has not been determined. The reason for this is that the energy of the $\mathrm{X}$-ray beam causes the decomposition and partial dehydration of the sabugalite. Thus thermal analysis may provide information on the structure of sabugalite which may not be obtained by single crystal X-ray diffraction procedures. Structural information on different minerals has successfully been obtained recently by sophisticated thermal analysis techniques [12-17].

Sabugalite was described as having endotherms in the DTA patterns at 191,244 and $320^{\circ} \mathrm{C}$ with a broad endotherm in the 380 to $450^{\circ} \mathrm{C}$ temperature range $[3,18]$. Thermogravimetry gave mass losses due to dehydration of 9 moles at $150^{\circ} \mathrm{C}, 4.5$ moles between 150 and $270^{\circ} \mathrm{C}$ and 3 moles in the 270 to $440^{\circ} \mathrm{C}$ temperature range. Čejka reported that the anhydrous (dehydrated) sabugalite phase decomposed with loss of oxygen and the resulting phase depended upon the temperature [8]. Ambartsumyan et al. reported dehydration at $100^{\circ} \mathrm{C}(7$ moles of water $), 200^{\circ} \mathrm{C}(4.5$ moles of water) and $300^{\circ} \mathrm{C}$ (4.5 moles of water) [19]. Vochten and Pelsmaekers reported three endotherms in the DSC curve of synthetic sabugalite at 50, 120 and $175^{\circ} \mathrm{C}$ corresponding to the water loss of 4 moles at $65^{\circ} \mathrm{C}, 7$ moles between 65 and $126^{\circ} \mathrm{C}$ and 5 moles

\footnotetext{
* Author for correspondence: r.frost@qut.edu.au
} 
between 126 and $220^{\circ} \mathrm{C}$ [18]. This variation of results depends on the sample whether natural or synthetic, the method of measurement such as TG, DTA or DSC and the initial hydration of the sabugalite.

Our interest in minerals with layered structures motivates this research as does the search for fundamental understanding of minerals that contain hydrated cations and phosphate or arsenate anions [20-23]. Uranium speciation is important in the safety assessment of nuclear waste repositories to predict actinide migration from such sites [24]. According to Clark et al. [25], actinide elements released to the environment will eventually come into contact with water, containing phosphate and/or hydrogen phosphate anions which are exceptionally strong complexing agents for actinide ions inclusive uranyl, $\left(\mathrm{UO}_{2}\right)^{2+}$. Such chemistry will result in the formation of autunite minerals including sabugalite. Such complexes may therefore play an important role in migration from a nuclear waste or in accidental site contamination. Knowledge of conditions of formation, paragenesis and paragenetic sequences, crystal structure, thermodynamic and other properties of the uranyl minerals are therefore indispensable also from the environmental point of view. Determination of such properties can be achieved by a number of techniques. Thermal analysis techniques enables the understanding not only crystal chemistry of uranyl natural and synthetic compounds, but also especially the role of water molecules and other $\mathrm{OH}$ groupings and hydrogen bonding in these uranyl phases.

In this work we report the thermal transformation of sabugalite, an oxonium-aluminium based uranyl phosphate, as determined by dynamic thermogravimetry and controlled rate thermal analysis.

\section{Experimental}

\section{Minerals}

The sabugalite mineral (mineral identification M42797) was obtained from Museum Victoria and originated from El Loba Mine, El Loba, La Hoba, Don Benito District, Badajoz, Spain. The mineral was analysed by X-ray diffraction for phase identification and by electron probe for chemical composition.

\section{Synthesis of sabugalite}

Sabugalite was synthesized by the reaction of uranyl acetate and aluminium chloride in the presence of phosphoric acid:

$$
\begin{gathered}
4 \mathrm{UO}_{2}(\mathrm{Ac})_{2}+\mathrm{AlCl}_{3}+4 \mathrm{H}_{3} \mathrm{PO}_{4} \rightarrow \\
\rightarrow \mathrm{HAl}\left(\mathrm{UO}_{2}\right)_{4}\left(\mathrm{PO}_{4}\right)_{4}+8 \mathrm{CH}_{3} \mathrm{COO}^{-}+11 \mathrm{H}^{+}+3 \mathrm{Cl}^{-}
\end{gathered}
$$

Uranyl acetate $\left(\mathrm{UO}_{2}\left(\mathrm{OOCCH}_{3}\right)_{2} \cdot 2 \mathrm{H}_{2} \mathrm{O}, 1.9339 \mathrm{~g}\right.$, 0.0043 mole) and aluminium chloride $\left(\mathrm{AlCl}_{3}, 0.145 \mathrm{~g}\right.$, 0.0011 mole) were both dissolved in ultrapure water, with final solution being $500 \mathrm{~cm}^{3}$. The $2 \mathrm{~cm}^{3}$ of phosphoric acid ( $85 \%$ solution, $2.873 \mathrm{~g}, 0.029$ mole) was made up to $100 \mathrm{~cm}^{3}$ with ultrapure water. The phosphoric acid solution was added dropwise to the above solution with constant stirring. Resulting suspension was left over night with gentle heating, at approx. $60^{\circ} \mathrm{C}$. The sabugalite was removed the following morning by filtration and was then washed with UP water and air dried. The synthesised mineral was also analysed by EDX and XRD techniques.

\section{Thermal analysis}

Thermal decomposition of the powdered mineral was carried out in a $\mathrm{TA}^{\circledR}$ Instruments incorporated highresolution thermogravimetric analyzer (series Q500) in a flowing nitrogen atmosphere $\left(80 \mathrm{~cm}^{3} \mathrm{~min}^{-1}\right)$. $34.4 \mathrm{mg}$ of sample underwent thermal analysis, with a heating rate of $5^{\circ} \mathrm{C} \mathrm{min}{ }^{-1}$, to $1000^{\circ} \mathrm{C}$.

In addition to this dynamic experiment, controlled-rate thermal analysis (CRTA) investigations were carried out, as well. In this case a relatively high amount of sample (approx. $140 \mathrm{mg}$ ) was heated in a labyrinth type crucible. This (platinum) crucible consists of tightly fitting lower and upper parts of conical shape. When the parts are put together, the air originally present is expelled by the gaseous decomposition products liberated at the beginning of the decomposition process and leave the crucible through a narrow channel of a spiral shape between the two parts thereby providing a pure (so-called self-generated) atmosphere. In this case the decomposition takes place under quasi-isobaric conditions excluding furnace gas from the inside of the crucible. Through the CRTA experiment the sample was heated at a relatively low rate $\left(1{ }^{\circ} \mathrm{C} \mathrm{min}^{-1}\right)$ until the decomposition was about to start. Then - with the quasi-isothermal, quasi-isobaric heating program of the instrument - the furnace temperature was regulated to provide (and maintained throughout the entire process of decomposition) a constant rate of $0.05 \mathrm{mg} \mathrm{min}^{-1}$. In this way time enough was provided to compensate for the inherently slow transport of heat from the furnace into the sample. When the decomposition was finished, the heating program changed, and the sample was dynamically heated again until the next decomposition was commenced.

\section{X-ray diffraction}

X-ray diffraction patterns were collected using a Philips X'pert wide angle X-ray diffractometer, operating in step scan mode, with $\mathrm{CuK}_{\alpha}$ radiation (1.54052 $\AA$ ). 
Patterns were collected in the range 3 to $90^{\circ} 2 \theta$ with a step size of $0.02^{\circ}$ and a rate of $30 \mathrm{~s}$ per step. Samples were prepared as a randomly orientated powder on a petroleum jelly coated glass slide. Data collection and evaluation were performed with PC-APD 3.6 software. Profile fitting was applied to extract information on the microstructure and structural defects of the mineral. The Profile Fitting option of the software uses a model that employs twelve intrinsic parameters to describe the profile, the instrumental aberration and wavelength dependent contributions to the profile.

\section{Electron probe microanalysis}

The scanning electron microscope (SEM) used to study the mineral was the FEI Quanta 200 SEM. The SEM was fitted with an EDAX thin-window X-ray detector. Samples examined under SEM consisted of small selected mineral chips mounted with doublesided carbon tape on aluminium stubs. The surface of samples was coated with a thin layer of carbon in a high vacuum coater to provide a good conductive surface. Elemental analyses were carried out with a qualitative energy dispersive $\mathrm{X}$-ray microanalysis at $25 \mathrm{kV}$ and $10 \mathrm{~mm}$ working distance.

\section{Results and discussion}

\section{$X$-ray diffraction}

The XRD patterns of the natural and synthetic sabugalite together with the XRD patterns of the thermally treated sabugalites are shown in Fig. 1. The natural sabugalite has an intense peak at $10.45^{\circ} 2 \theta$ corresponding to a $d$-spacing of $8.46 \AA$. In comparison the synthetic sabugalite shows two spacings at 9.56 and $8.67 \AA$. The published data gives a value of $9.63 \AA$. The synthetic sabugalite is apparently different to that of the natural mineral. This difference in $d(001)$ spacings is easily accounted for by the arrangement of the cations and the water in the interlayer. Thermal treatment of the natural sabugalite results in the spacing of $8.35 \AA$. The spacing for the thermally treated synthetic sabugalite is $9.01 \AA$.

\section{Electron probe analysis}

The SEM image of synthetic sabugalite is shown in Fig. 2. The morphology of the sabugalite crystals can be readily observed. Many of the crystals are larger than $20 \mu \mathrm{m}$. The mica-like characteristics of the mineral can be readily seen. The EXD analyses of different crystals of sabugalite show the mineral to contain $\mathrm{U}, \mathrm{Al}$ and $\mathrm{P}$. It is probable that the sabugalite should be written as $\left.\left(\mathrm{H}_{3} \mathrm{O}\right) \mathrm{Al}\right)_{2}\left(\mathrm{UO}_{2}\right)_{8}\left(\mathrm{PO}_{4}\right)_{8} \cdot 30 \mathrm{H}_{2} \mathrm{O}$. The empirical oxide formula for sabugalite can be written $4 \mathrm{UO}_{3}: 2 \mathrm{P}_{2} \mathrm{O}_{5}: 0.5 \mathrm{Al}_{2} \mathrm{O}_{3}: 16.5 \mathrm{H}_{2} \mathrm{O}$ (or, equivalently, $8 \mathrm{UO}_{3}: 4 \mathrm{P}_{2} \mathrm{O}_{5}: \mathrm{Al}_{2} \mathrm{O}_{3}: 33 \mathrm{H}_{2} \mathrm{O}$ ). The hydrated $\mathrm{H}^{+}$ion located in the interlayer must eventually evolve as 0.5 mass $\% \mathrm{H}_{2} \mathrm{O}$ upon complete decomposition of sabugalite. Thus, the calculated mass percent of $\mathrm{H}_{2} \mathrm{O}$ in sabugalite is $16.73 \%$.

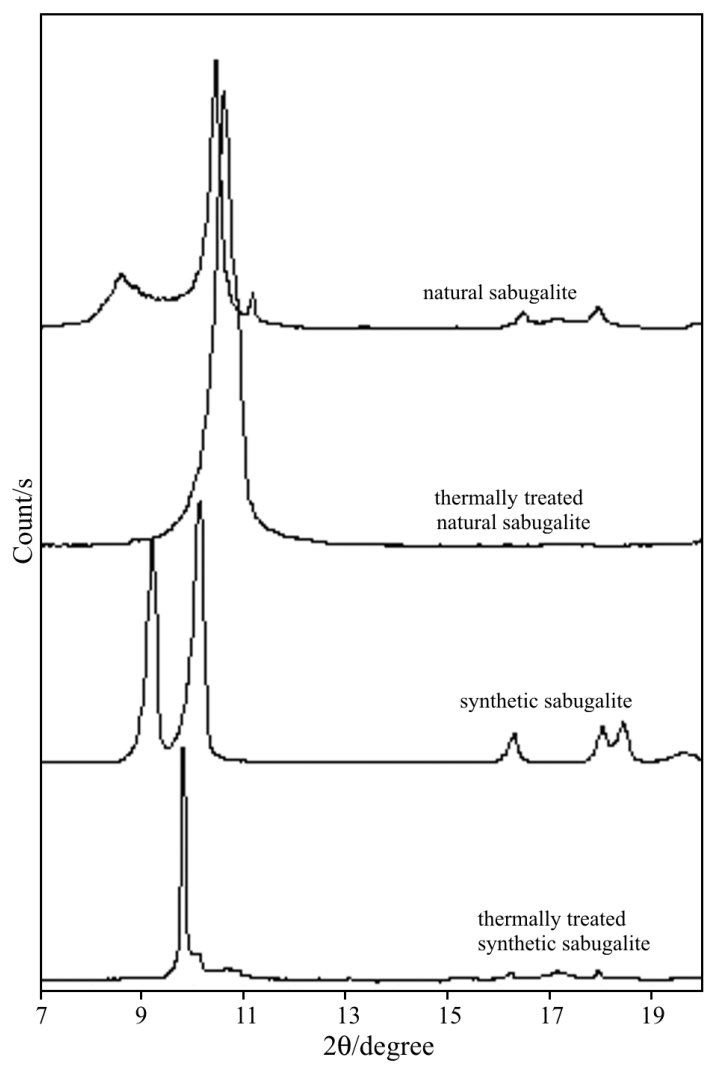

Fig. 1 X-ray diffraction patterns of sabugalite, synthetic sabugalite, thermally treated sabugalite and thermally treated synthetic sabugalite

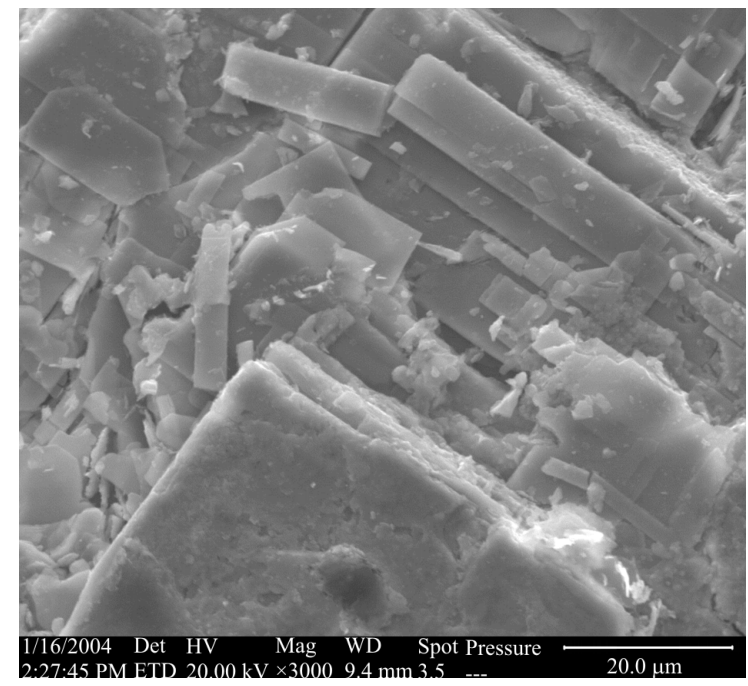

Fig. 2 SEM image of synthetic sabugalite 


\section{Thermal analysis}

The thermogravimetric analysis of the sabugalite is shown in Fig. 3. Four mass loss steps are observed for the dehydration of sabugalite. These occur at $48^{\circ} \mathrm{C}$ (temperature range 39 to $59^{\circ} \mathrm{C}$ ), $84^{\circ} \mathrm{C}$ (temperature range 59 to $109^{\circ} \mathrm{C}$ ), $127^{\circ} \mathrm{C}$ (temperature range 109 to $165^{\circ} \mathrm{C}$ ) and around $270^{\circ} \mathrm{C}$ (temperature range 175 to $525^{\circ} \mathrm{C}$ ) with mass losses of $2.8,6.5,2.3$ and $4.4 \%$, respectively, making a total mass loss of water of $16.0 \%$. The density of sabugalite $\left(3.2 \mathrm{~g} \mathrm{~cm}^{-3}\right)$ indicates two formula units per unit cell $(Z=2)$. This requires $32 \mathrm{H}_{2} \mathrm{O}$ groups, rather than 16 per unit cell in the formula as is normally written. It means that in terms of a structural unit the formula would be better written as $\left.\left(\mathrm{H}_{3} \mathrm{O}\right) \mathrm{Al}\right)_{2}\left(\mathrm{UO}_{2}\right)_{8}\left(\mathrm{PO}_{4}\right)_{8} \cdot 30 \mathrm{H}_{2} \mathrm{O}$. Writing the formulas above means that $\sim 0.5$ mass $\% \mathrm{H}_{2} \mathrm{O}$ will be retained after dehydration. It is possible that the $\mathrm{H}_{3} \mathrm{O}^{+}$is retained in the interlayer and is hydrated just as the $\mathrm{Al}^{3+}$ ion. The theoretical mass loss of sabugalite is $16.73 \%$. The theoretical mass loss steps for sabugalite based upon the loss of 5, 13, 5 and 9 moles are $2.54,6.59,2.54$ and $4.56 \%$. Thus the experimentally determined result is in good agreement with the theoretically predicted value.

\section{Controlled rate thermal analysis}

The thermoanalytical curves of $139.40 \mathrm{mg}$ sabugalite recorded under CRTA conditions are shown in Fig. 4. A small amount of adsorbed water $(0.71 \%)$ was lost at $50^{\circ} \mathrm{C}$. The mass loss stages at 60 and $97^{\circ} \mathrm{C}$ correspond to the removal of 2.09 and $5.81 \%$ water, respectively. In these processes the temperature remained spontaneously constant. Upon further heating a mass loss of $5.93 \%$ is observed, but the rate of decomposition did not reach the pre-set level of $0.05 \mathrm{mg} \mathrm{min}^{-1}$. As a consequence, the temperature did not remained constant (it increased slowly from 120 to $220^{\circ} \mathrm{C}$ in about $200 \mathrm{~min}$ ). After about $450 \mathrm{~min}$ the temperature increased according to the dynamic program (offCRTA condition), i.e. at $1^{\circ} \mathrm{C} \mathrm{min}{ }^{-1}$. Between 220 and $330^{\circ} \mathrm{C}$ a shoulder can be observed in the DTG

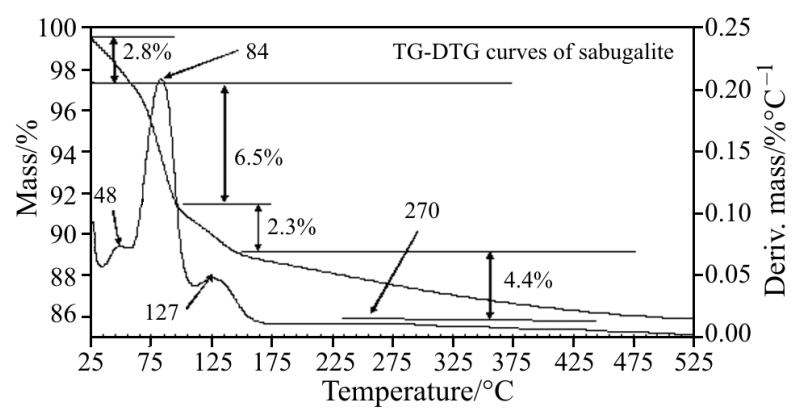

Fig. 3 Thermogravimetry of sabugalite in the 25 to $500^{\circ} \mathrm{C}$ temperature range

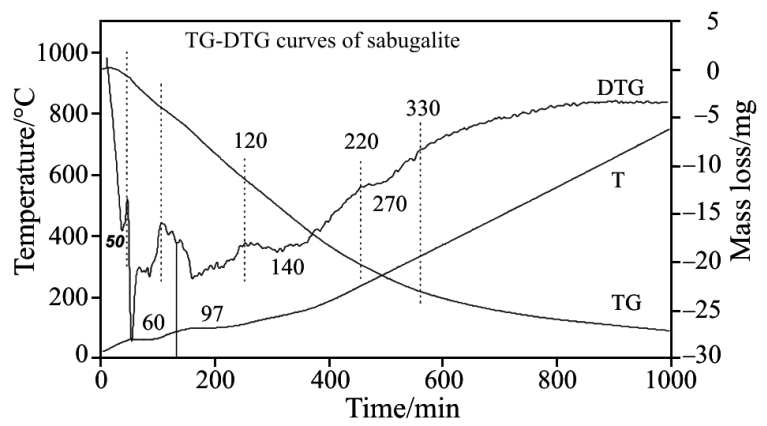

Fig. 4 Controlled-rate thermal analysis of synthetic sabugalite

curve resulting in a mass loss of $2.04 \%$. After this temperature a monotonous mass loss can be observed up to approx. $1000^{\circ} \mathrm{C}$ leading to a loss of $2.87 \%$.

The thermal behaviour of the mineral can be explained as follows. The shapes of conventional thermoanalytical curves depend almost exclusively on heat and mass transfer processes, while other elementary processes (such as nucleation, recrystallization) remain usually hidden. If a Q-TG curve has a quasi-isothermal course, it is controlled only by the transport of heat and gas. In this case even if other elementary processes are involved, they are always faster than the heat and gas transport. With the combination of the labyrinth-type sample holder and the quasi-isothermal heating technique, the first two steps of dehydration take place under quasi-isothermal, quasi-isobaric - and quasi-equilibrium - conditions. The decomposition temperatures of 60 and $97^{\circ} \mathrm{C}$ can be considered as the normal (thermodynamic) decomposition temperatures. Most likely the third dehydration stage would also have been an isothermal one, had the rate of decomposition reached the $0.05 \mathrm{mg} \mathrm{min}^{-1}$ level. Based on the observed mass loss values, the amounts of crystallization water liberated in the subsequent dehydration processes are 2.06, 5.73, 5.85, and $2.01 \mathrm{~mol}$, respectively. Thus, the mechanism for the dehydration of sabugalite is as follows.

\section{Mechanisms for the dehydration of sabugalite}

- Stage 1: formation of meta(I)sabugalite from sabugalite

$$
\begin{gathered}
(\mathrm{HAl})\left(\mathrm{UO}_{2}\right)_{4}\left(\mathrm{PO}_{4}\right)_{4} \cdot 16 \mathrm{H}_{2} \mathrm{O} \rightarrow \\
\rightarrow(\mathrm{HAl})\left(\mathrm{UO}_{2}\right)_{4}\left(\mathrm{PO}_{4}\right)_{4} \cdot 14 \mathrm{H}_{2} \mathrm{O}+2 \mathrm{H}_{2} \mathrm{O}\left(60^{\circ} \mathrm{C}\right)
\end{gathered}
$$

- Stage 2: formation of meta(II)sabugalite

$$
\begin{gathered}
(\mathrm{HAl})\left(\mathrm{UO}_{2}\right)_{4}\left(\mathrm{PO}_{4}\right)_{4} \cdot 14 \mathrm{H}_{2} \mathrm{O} \rightarrow \\
\rightarrow(\mathrm{HAl})\left(\mathrm{UO}_{2}\right)_{4}\left(\mathrm{PO}_{4}\right)_{4} \cdot 8 \mathrm{H}_{2} \mathrm{O}+6 \mathrm{H}_{2} \mathrm{O}\left(97^{\circ} \mathrm{C}\right)
\end{gathered}
$$

- Stage 3: formation of meta(III)sabugalite

$$
\begin{gathered}
(\mathrm{HAl})\left(\mathrm{UO}_{2}\right)_{4}\left(\mathrm{PO}_{4}\right)_{4} \cdot 8 \mathrm{H}_{2} \mathrm{O} \rightarrow \\
\rightarrow(\mathrm{HAl})\left(\mathrm{UO}_{2}\right)_{4}\left(\mathrm{PO}_{4}\right)_{4} \cdot 2 \mathrm{H}_{2} \mathrm{O}+6 \mathrm{H}_{2} \mathrm{O}\left(120-220^{\circ} \mathrm{C}\right)
\end{gathered}
$$


- Stage 4: formation of anhydrous uranyl phosphate (as per XRD pattern)

$$
\begin{gathered}
(\mathrm{HAl})\left(\mathrm{UO}_{2}\right)_{4}\left(\mathrm{PO}_{4}\right)_{4} \cdot 2 \mathrm{H}_{2} \mathrm{O} \rightarrow \\
\rightarrow(\mathrm{HAl})\left(\mathrm{UO}_{2}\right)_{4}\left(\mathrm{PO}_{4}\right)_{4}+2 \mathrm{H}_{2} \mathrm{O}\left(220-330^{\circ} \mathrm{C}\right)
\end{gathered}
$$

Above $330^{\circ} \mathrm{C}(600 \mathrm{~min})$ the slow mass loss stage belongs to the degradation of the anhydrous mineral, most likely along with the liberation of water (hydride elimination).

The difference in the TG results may depend upon the way in which the analyses were undertaken. One element that is common to all the TG results is that there are at least three steps in the dehydration of metasabugalite. In this work we suggest that there are four dehydration steps of sabugalite; the first three are of equilibrium nature under CRTA conditions.

\section{Conclusions}

The use of different analytical techniques combined with controlled rate thermal analysis of sabugalite has enabled a definitive analysis of the thermal decomposition of sabugalite. While the temperature ranges and the mass losses published obviously vary from author to author due to the different experimental conditions, the results of the CRTA analysis should be considered as standard data due to the quasi-equilibrium nature of the thermal decomposition process. Thus the mineral studied is sabugalite of the formula $(\mathrm{HAl})_{1 / 2}\left[\left(\mathrm{UO}_{2}\right)_{2}\left(\mathrm{PO}_{4}\right)\right]_{2} \cdot 8 \mathrm{H}_{2} \mathrm{O}$. The four steps observed for the dehydration of sabugalite occur at $50^{\circ} \mathrm{C}$ with the loss of 2 moles of water, $60^{\circ} \mathrm{C}$ with the loss of 6 moles of water, $140^{\circ} \mathrm{C}$ with the loss of an additional 6 moles of water and at higher temperatures with the loss of a further two moles of water.

\section{Acknowledgements}

The financial and infra-structure support of the Queensland University of Technology Inorganic Materials Research Program of the School of Physical and Chemical Sciences is gratefully acknowledged. The Australian Research Council (ARC) is thanked for funding. Mr Dermot Henry of Museum Victoria is thanked for the loan of the sabugalite.

\section{References}

1 P. Burns, Rev. Miner., 38 (1999) 23.

2 H. Isobe, R. C. Ewing and T. Murakami, Mater. Res. Soc. Symp. Proc., 333 (1994) 653.

3 J. Čejka, Z. Urbanec, J. Čejka, Jr., J. Ederova and A. Muck, J. Thermal Anal., 33 (1988) 395.

4 T. L. Ambartsumyan, Atomnaya Energ., Voprosy Geol. Urana, Suppl., (1957) 86.

5 J. Čejka, J. Čejka Jr. and A. Muck, Thermochim. Acta, 86 (1985) 387.

6 T. Muto, Mineral J., 4 (1965) 245.

7 J. Čejka, Jr., A. Muck and J. Čejka, Neues Jahrbuch fuer Mineralogie, Monatshefte, (1985) 115.

8 J. Čejka, Rev. Miner., 38 (1999).

9 A. Muck, J. Čejka, Jr., J. Čejka and Z. Urbanec, Sbornik Vysoke Skoly Chemicko-Technologicke v Praze, B: Anorganicka Chemie a Technologie, B31 (1986) 71.

10 A. J. Locock and P. C. Burns, Am. Mineral, 88 (2003) 240.

11 J. Čejka, Jr., A. Muck and J. Čejka, Phys. Chem. Miner., 11 (1984) 172.

12 R. L. Frost and K. L. Erickson, J. Therm. Anal. Cal., 76 (2004) 217.

13 E. Horváth, J. Kristóf, R. L. Frost, N. Heider and V. Vágvölgyi, J. Therm. Anal. Cal., 78 (2004) 687.

14 R. L. Frost, M. L. Weier and K. L. Erickson, J. Therm. Anal. Cal., 76 (2004) 1025.

15 R. L. Frost and K. L. Erickson, J. Therm. Anal. Cal., 78 (2004) 367.

16 E. Horváth, J. Kristóf, R. L. Frost, A. Rédey, V. Vágvölgyi and T. Cseh, J. Therm. Anal. Cal., 71 (2003) 707.

17 J. Kristóf, R. L. Frost, J. T. Kloprogge, E. Horváth and E. Makó, J. Therm. Anal. Cal., 69 (2002) 77.

18 R. Vochten and J. Pelsmaekers, Phys. Chem. Miner., 9 (1983) 23.

19 T. L. Ambartsumyan, G. I. Basalova, S. A. Gorzhevskaya, N. G. Nazarenko and R. P. Khodzhayeva, Gosatomizdat, (1961) 148.

20 W. Martens, R. L. Frost and P. A. Williams, J. Raman Spectrosc., 34 (2003) 104.

21 W. N. Martens, R. L. Frost, J. T. Kloprogge and P. A. Williams, Am. Mineral., 88 (2003) 501.

22 R. L. Frost, T. Kloprogge, M. L. Weier, W. N. Martens, Z. Ding and H. G. H. Edwards, Spectrochim. Acta, Part A 59 (2003) 2241.

23 R. L. Frost, M. L. Weier, W. Martens, J. T. Kloprogge and Z. Ding, Thermochim. Acta, 403 (2003) 237.

24 S. N. Kalmykov and G. R. Choppin, Radiochim. Acta, 88 (2000) 603.

25 D. L. Clark, D. E. Hobart and M. P. Neu, Chem. Rev., 95 (1995) 25.

Received: January 22, 2005

Accepted: March 23, 2005

OnlineFirst: January 11, 2006

DOI: $10.1007 / \mathrm{s} 10973-005-6916-0$ 